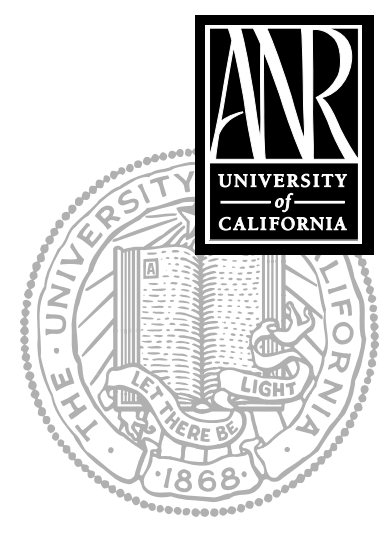

UNIVERSITY OF CALIFORNIA

Division of Agriculture and Natural Resources http://anrcatalog.ucdavis.edu

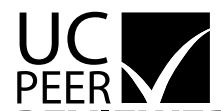
REVIEWED

\title{
Plant Genetic Engineering and Intellectual Property Protection
}

BRIAN D. WRIGHT, Professor of Agricultural and Resource Economics, University of California, Berkeley

\section{Were rights to plant varieties protected prior to the development of genetically} engineered varieties?

Three kinds of protection have been available for some time. Legal protection of plant varieties was introduced in the United States long before the development of genetically engineered plants. Since 1930 a type of patent introduced especially for plants, known as a "plant patent," has been available from the U.S. Patent and Trademark Office (USPTO) in the Department of Commerce to protect novel clonally propagated (i.e., asexually reproduced) plant varieties including fruit trees, ornamentals, and berries. Plant patents, like the more common and much older utility patents available for inventions, are currently enforceable from the date they are granted until 20 years from the date of application. Since 1970, Plant Variety Protection Certificates (PVPCs) have been available from the U.S. Department of Agriculture. The term of protection offered under a PVPC is now 20 years for most crops, 25 for trees and vines. Farmers are allowed to save seed of varieties protected by PVPCs for replanting their crops, but they cannot provide or sell those seeds to others for planting. Varieties eligible for protection are those that are new, uniform, stable (in the sense of reproducing their characteristics in their progeny), and distinct from existing varieties. It is important to note that plant patents and PVPCs prevent only unlawful proliferation of the variety; they do not prevent the use of protected plant materials for breeding purposes. In contrast, the more broad-ranging utility patents not only prevent seed increase via reproduction of the same variety, they also protect breeders against unauthorized use of protected varieties for breeding and research purposes.

A third means of production is hybridization. Seed saved from a hybrid crop (produced from different male and female parental varieties) does not yield nearly as highly as the initial hybrid crop. Thus, breeders of hybrid crops have an effective nonlegal protection against replanting by farmers. Heavy private investment in crop breeding has tended to be concentrated in hybrids, in particular hybrid corn and hybrid horticultural crops. For other crops, most breeding-related research has until recently been largely concentrated in the public sector, in agricultural experiment stations and universities (Wright et al. 2005).

\section{What kinds of intellectual property protection are available for plant breeders today?}

The development of genetic engineering of plants in the 1980s was accompanied by a sequence of increasingly specific confirmations of the patentability of various types of life forms, provided that they met the standard patent criteria of novelty, utility, and nonobviousness. The 1980 Supreme Court decision in Diamond v. Chakrabarty (44 U.S. 303, 1980) held that regular utility patents could be granted for inventions involving living organisms. This decision specifically addressed the patentability of a newly created microorganism that could break down crude in a manner that might be useful to control oil spills. Subsequent U.S. Patent and Trademark Office and Supreme Court decisions confirmed that plants and animals, including those created by conventional breeding, and particular sequences of genetic material or DNA such as genes, markers, and promoters (which control the expression of genes in cells), could be protected by utility patents. 
Utility patent protection is also available for novel methods of breeding and genetic engineering, for new varieties produced by these methods. and for research tools. A novel plant might, for example, be protected by a utility patent on the variety or on its genes, by a plant patent or PVPC, or by a combination of these means. A plant might also be patented as a product of the novel method by which it was produced, such as genetic engineering. Utility patents protect the plant breeders' or inventors' rights to control the use, sale, import, and reproduction of plants that have been patented or that incorporate patented material. This means that, using utility patents, plant breeders can dictate the terms under which such plants can be used and can prevent others from using them for any subsequent breeding or for seed increase via replanting of the harvested seed. Utility patents also restrict public or private research uses of patented materials and methods.

Today, utility patents, plant patents, PVPCs, and state laws that protect trade secrets (valuable proprietary information held by a corporation or its employees) are used by U.S. breeders, including seed companies, experiment stations, and universities, to protect the fruits of their breeding and research. The choice of which one or more of the various protective measures to use is influenced by their eligibility for the various means of protection and the relative cost and effectiveness of enforcement of each means of protection. The new molecular and genomic tools used in genetically engineering plants have also vastly enhanced the enforceability of intellectual property protection by providing new and more powerful means of establishing that someone has illegally used a protected variety. It is now possible to definitively characterize plants and seeds at the molecular level by establishing their unique "fingerprints" in a manner similar to that used for DNA profiling in criminal cases. It is also possible to detect the use of protected varieties or genetic material in breeding new varieties.

\section{How do patent holders control the use of their varieties, genetic materials, and methods?}

The terms of commercial transactions in seeds or other plant genetic material can include protection of the inventions embodied in the material by

- explicit licenses signed by buyers (breeders or farmers) that restrict resale or use of the material in breeding or for production of seed for replanting.

- bag label contracts (like "shrink-wrap" contracts for software) that restrict the use of the materials by farmers and others.

- Material Transfer Agreements (MTAs), which contractually define the rights and obligations of recipients with respect to these materials.

- "Technology Use Agreements," contracts restricting the use of plant genetic material by farmers. For example, such an agreement could restrict sowing of seeds to a specified area of land. It might also allow the provider of the seeds to test the farmer's crops for several years in the future, to check that the farmer does not violate the terms of relevant licenses or other contracts.

The intellectual property protections of plants and plant breeding described above are at most national in scope. Plant breeders' rights similar to U.S. plant variety protection are available in other countries that are members of the International Union for the Protection of New Varieties of Plants (known by its French acronym, UPOV). Membership in UPOV is proliferating globally as developing countries that are members of the World Trade Organization (WTO) attempt to comply with provisions of the 1994 Trade-related Aspects of Intellectual Property Rights agreement (TRIPS; see http://www.wto.org/english/docs_e/legal_e/27-trips.pdf), which was designed to ensure minimum standards of intellectual property protection among WTO member countries. This agreement requires a minimum standard for awarding patent protection, 
but it allows member countries to adopt their own unique ("sui generis") systems of protection specifically designed for plant varieties as alternatives to utility patents for plants. Plant variety protection consistent with UPOV guidelines is generally thought to qualify as such a sui generis alternative under TRIPS.

Many countries do not allow patenting of plant varieties (Boettiger et al. 2004). Contractual restrictions can in some cases substitute for patent protection in such countries, and plant variety protection is available not only for sexually reproduced varieties, but also for clones such as vines and rootstocks that would qualify for plant patent protection in the United States. But in many countries, lack of the more powerful utility patent protection (or lack of effective enforcement of patent rights) can be a serious obstacle for companies that would otherwise be interested in introducing new and superior plant varieties.

\section{How can the legal restrictions on plants and plant breeding be enforced?}

Intellectual property rights in plants and plant breeding materials and methods can be enforced by lawsuits against infringers. Many patent infringement lawsuits involve competing breeders, biotech firms, and/or universities. Lawsuits against farmers and agricultural biotechnology firms may involve allegations of patent infringement or violation of licenses, bag-label contracts, or provisions of technology use agreements. Damages paid by infringing farmers typically do not cover the expenses incurred by the firms. Such lawsuits appear to be economically justified only if they serve more broadly to discourage others from infringing.

\section{What has been the effect of patents on development of new varieties?}

Enhanced intellectual property protection is widely credited with providing an incentive for the increased private investment in crop breeding and genetic engineering since the 1980s. Possession of patents is often viewed as necessary for attracting outside investment in a startup biotech company. However, the high cost of transactions involving intellectual property rights is one factor that has encouraged the mergers and consolidation that have occurred since 1995 involving companies engaged in the genetic engineering of plants (Graff, Rausser, and Small 2003; Graff et al. 2003). Entry by new firms has been discouraged by the need to negotiate a growing "thicket" of existing patent claims on important technologies. Private plant genetic engineering is now dominated by a handful of firms. One, Monsanto, currently accounts for about half of all U.S. field trials and the dominant share of commercial acreage of genetically engineered crops.

Earlier attempts to commercialize genetically engineered potatoes, tomatoes, tobacco, and wheat have been abandoned in the face of low profitability and consumer acceptance issues. Leading agricultural biotechnology firms have increasingly focused on a small set of crops with large markets of high aggregate value, including soybeans, corn, cotton, and canola. These crops, genetically engineered by a handful of private multinational firms for traits valued by farmers, including herbicide tolerance, and pest resistance conferred by genetic material from a bacterium, Bacillus thuringiensis (Bt), have been widely and rapidly adopted in the Americas. There has also been substantial adoption of genetically modified crops in Argentina, Brazil, China, India, South Africa, Australia, and elsewhere (James 2005), with the prominent exception of countries where consumer opposition to genetically engineered crops is strong, including Japan, and some members of the European Union where major chemical crop protection firms threatened by genetic engineering are based. 


\section{Why haven't genetically engineered varieties of "minor crops," like those grown in California, become available to farmers?}

Responsibility for breeding many other crops such as wheat, barley, rice, and "orphan" or small acreage crops (other than hybrid horticultural crops) still lies primarily with the public sector. Over the past century or so public-sector breeding has yielded a very high rate of return on the public's investment (Alston et al. 2000; Huffman and Evenson 1993). But financial support for such research is waning, while costs for the field trials and the gathering of the regulatory data necessary to gain approval of genetically engineered crops are now very high. The extent to which small-acreage crops will benefit from genetic engineering is uncertain. Public-sector breeders must generally collaborate with the private sector to access the financial and physical resources needed to bring a crop to market. Unfortunately, there has been a decline in the opportunities to develop plant breeding innovations with startup firms or seed companies. The causes of this decline include issues related to consumer acceptance, the costs of conducting field trials, and the expenses associated with meeting other regulatory requirements.

Problems have also been caused by restrictions imposed by prior public or private intellectual property rights (Wright 1998). Under the Bayh-Dole Act of 1980, universities and other research institutions retain ownership of inventions produced by their researchers or breeders with the support of federal funds. Many patented basic materials and methods for genetic engineering in agriculture were generated either in private corporations or in universities and are often licensed exclusively to private businesses (Boettiger and Bennett 2006). Today "patent thickets" entwine some of the key technologies and materials, hindering their application in public-sector research on plant breeding. To facilitate access of scientists in the public sector and small companies to publicly generated innovations, the Public Intellectual Property Resource for Agriculture (PIPRA; see http://www.pipra.org/) initiative encourages strategic management of legally protected technology to facilitate access of all its members for research and humanitarian uses (Atkinson et al. 2003). The Specialty Crops Regulatory Initiative aims to reduce the high cost of regulation for such crops. Biotechnology for an Open Society (BIOS; http://www.bios.net/) seeks to generate open-source development of suites of research tools for biotechnology innovation, unhindered by any patent thickets (Nature 2004).

\section{PERSPECTIVE}

Since the 1980s, intellectual property protection for crop breeding innovations in the United States has expanded, and its enforcement has been strengthened. This has encouraged the development, introduction, and rapid adoption of highly successful transgenic varieties of soybeans, cotton, corn, and canola. But the prospects for successful development and diffusion of genetically engineered cultivars of small-acreage crops, including some of major significance to California, are not clear. Challenges include consumer opposition to genetically modified food, the high cost of regulatory compliance, and difficulties in obtaining access to the relevant intellectual property rights. Regulatory costs are being addressed in the Specialty Crops Regulatory Initiative, and PIPRA and BIOS are addressing problems posed by intellectual property protection of key technologies.

Intellectual property protection rewards innovation and encourages private-sector plant breeding and genetic engineering that can enhance agricultural productivity. However, critics point out that the allocation of rights lacks balance. It does not recognize or reward the contribution of communities of farmers who have developed, over long periods of time, the landraces that form the basis of the pedigrees of modern crop varieties. Moreover, farmers who grow nontransgenic crops fear that they will bear the cost of contamination of their crops by drifting transgenic pollen, and they are also 
concerned about identity preservation of their products if transgenic varieties are included in the market chain.

Strengthening intellectual property rights has undoubtedly been important in stimulating the research and development that made genetically engineered varieties of major crops available to farmers. But legal control of key technologies and materials is one of several important factors, including regulatory costs and market acceptance, that have hindered the development of other genetically engineered crops, in particular small-acreage crops that are important to California.

\section{REFERENCES}

Alston, J. M., M. C. Marra, P. G. Pardey, and T. J. Wyatt. 2000. A meta analysis of rates of return to agricultural R\&D: Ex pede herculem? IFPRI Research Report No. 113. Washington, D.C.: International Food Policy Research Institute.

Atkinson, R., R. Beachy, G. Conway, F. Cordova, M. A. Fox, K. Holbrook, D. Klessig, R. McCormick, P. McPherson, H. Rawlings, B. Rapson, L. Vanderhoef, J. Wiley, and C. Young. 2003. Public sector collaborations for agricultural IP management. Science 301:174-175.

Boettiger, S., and A. B. Bennett. 2006. Bayh-Dole: If we knew then what we know now. Nature Biotechnology 24(3):320-323.

Boettiger S., G. Graff, P. G. Pardey, E. van Dusen, and B. D. Wright. 2004. Intellectual property rights for plant biotechnology: International aspects. In P. Christou and H. Klee, eds., Handbook of plant biotechnology. Chichester, UK: Wiley.

Graff, G. D., G. C. Rausser, and A. A. Small. 2003. Agricultural biotechnology's complementary intellectual assets. Review of Economics and Statistics 85(2):349-363.

Graff, G. D., S. E. Cullen, K. J. Bradford, D. Zilberman, and A. B. Bennett. 2003. The public-private structure of intellectual property ownership in agricultural biotechnology. Nature Biotechnology 21(9):989-995.

Huffman, W. E., and R. E. Evenson. 1993. Science for agriculture: A long-term perspective. Ames: Iowa State University Press.

James, C. 2005. Global status of commercialized biotech/GM crops: 2005. ISAAA Brief No. 34-2005. Ithaca, NY: International Service for the Acquisition of Agri-Biotech Applications.

Nature. 2004. Open-source biology. Nature 431:491.

Wright, B. D. 1998. Public germplasm development at a crossroads: Biotechnology and intellectual property. California Agriculture 52(6):8-13.

Wright, B. D., P. G. Pardey, C. Nottenburg, and B. Koo. 2005. Agricultural innovation: Economic incentives and institutions. In R. E. Evenson, P. Pingali, and T. P. Schultz, eds., Handbook of agricultural economics. Vol. 3. Amsterdam: Elsevier. 
To order or obtain printed ANR publications and other products, visit the ANR Communication Services online catalog at http://anrcatalog.ucdavis.edu. You can also place orders by mail, phone, or FAX, or request a printed catalog of our products from:

University of California

Agriculture and Natural Resources

Communication Services

6701 San Pablo Avenue, 2nd Floor

Oakland, California 94608-1239

Telephone: (800) 994-8849 or (510) 642-2431

FAX: (510) 643-5470

E-mail inquiries: danrcs@ucdavis.edu

An electronic version of this publication is available on the ANR Communication Services Web site at http://anrcatalog.ucdavis.edu.

\section{Publication 8186}

(c) 2006 by the Regents of the University of California, Division of Agriculture and Natural Resources. All rights reserved.

The University of California prohibits discrimination or harassment of any person on the basis of race, color, national origin, religion, sex, gender identity, pregnancy (including childbirth, and medical conditions related to pregnancy or childbirth), physical or mental disability, medical condition (cancer-related or genetic characteristics), ancestry, marital status, age, sexual orientation, citizenship, or status as a covered veteran (covered veterans are special disabled veterans, recently separated veterans, Vietnam era veterans, or any other veterans who served on active duty during a war or in a campaign or expedition for which a campaign badge has been authorized) in any of its programs or activities. University policy is intended to be consistent with the provisions of applicable State and Federal laws.

Inquiries regarding the University's nondiscrimination policies may be directed to the Affirmative Action/Staff Personnel Services Director, University of California, Agriculture and Natural Resources, 1111 Franklin Street, 6th Floor, Oakland, CA 94607-5201 (510) 987-0096. For a free catalog of other publications, call (800) 994-8849. For help downloading this publication, call (530) 754-5112.

Patent law is a complex and constantly evolving field. This publication describes current trends and conditions and does not provide advice or guidance. For such advice or guidance, consult an attorney.

This publication has been anonymously peer reviewed for technical accuracy by University of California scientists and other qualified professionals. This review process was managed by the ANR Associate Editor Chair.

pr-07/06-SB/RW 